\title{
MR. JUSTICE FRANKFURTER AND ADMINISTRATIVE LAW
}

\author{
NATHANIEL L. HATHAHSON $\dagger$
}

\section{Separation of Powers}

When Professor Felix Frankfurter taught Administrative Law at the Harvard Law School, he did so, characteristically, in the grand manner. He could not have done otherwise, for his basic concern was the affairs of government in their broadest sweep. To attempt to emulate his manner here, in considering the judicial labors of Mr. Justice Frankfurter in the domain of administrative law, would do honor neither to the Professor nor to the Justice. Nevertheless, it is fitting that we should at least approach the subject matter as he was wont to view it, with a principal focus on the appropriate boundaries of legislative, executive and judicial powers.

Within this framework, Youngstown Sheet \& Tube Co. v. Sawyer is the obvious point of departure. ${ }^{1}$ No other case ever to come before the Court presented so starkly the problem of differentiating between executive and legislative powers; no other required the judiciary to be more conscious of the delicacy of its own role in undertaking to define the limits of the other two branches of government. Consistent with his concern for the inherent limitations of judicial power, Justice Frankfurter was apparently more ready than any other member of the Court to entertain seriously the suggestion that the controversy presented was not an appropriate one for judicial resolution. Thus he thought the Court's first inquiry:

"... must be not into the powers of the President, but into the powers of a District Judge to issue a temporary injunction in the circumstances of this case. Familiar as that remedy is, it remains an extraordinary remedy. To start with a consideration of the relation between the President's powers and those of Congress-a most delicate matter that has occupied the thoughts of statesmen and judges since the Nation was founded and will continue to occupy their thoughts as long as our democracy lasts-is to start at the wrong end. A plaintiff is not entitled to an injunction if money damages would fairly compensate him for any wrong he may have suffered."2

That one so wedded to the avoidance of premature constitutional adjudication should then dispose of this possibility of adequate damages at law by a rather enigmatic reference to the "same considerations by which the Steelworkers, in their brief amicus, demonstrate, from the seizure here in controversy, consequences that cannot be translated into dollars and cents" is perhaps a little

$\dagger$ Professor of Law, Northwestern University.

1. 343 U.S. 579 (1952).

2. Id. at 595 . 
surprising. ${ }^{3}$ Examination of the Steelworkers' brief reveals that they were most concerned with the loss of bargaining power, resulting from the temporary restraining order precluding any change in the terms and conditions of employment. Presumably, Mr. Justice Frankfurter meant to suggest that whatever the result in dollars and cents, the steel companies were entitled to an effective role in determining wages and other terms of employment, free from unauthorized governmental domination. While the hypothesis cannot be tested, the Justice's experience in labor affairs quite likely satisfied him that dismissal of the law suit would have given permanent effect to the War Labor Board's recommendations for settling the dispute and probably rendered academic any claims for damages. However that may be, there can be no doubt of the emotional as well as intellectual sincerity of the Justice's avowal that only "with the utmost unwillingness, with every desire to avoid judicial inquiry into the powers and duties of the other two branches of the government" was he compelled to "consideration of the legality of Executive Order No. 10340."4

Once the jurisdictional hurdle was overcome, Mr. Justice Frankfurter must have had little difficulty with the ultimate merits of the issue presented in the Youngstown case. The broad view of executive power expressed by Chief Justice Taft in the Myers case, ${ }^{5}$ and vigorously rejected by Justices Holmes and Brandeis in the same context, could hardly have commended itself to him. On the other hand, the Justice could not be completely content with the simplified rationalization of the conclusion offered by Mr. Justice Black-that the President had attempted to exercise legislative rather than executive powers because "the President's order does not direct that a congressional policy be executed in a manner prescribed by Congress-it directs that a presidential policy be executed in a manner prescribed by the President."6 Nor did he entirely accept the position that the Labor Management Relations Act of 1947 was in itself sufficient to establish the invalidity of the President's order. Although he gave considerable weight to the determination of Congress not to include seizure powers in the Labor Act, he restricted the scope of his concurrence even further: "We must therefore put to one side consideration of what powers the President would have had if there had been no legislation whatever bearing on the authority asserted by the seizure, or if the seizure had been only for a short, explicitly temporary period, to be terminated automatically unless Congressional approval were given."7 Finally, Mr. Justice Frankfurter characteristically closed his opinion with an appreciation of the President's "concern for the Nation's well-being" as well as an expression of disbelief that "the patriotism and the wisdom of the President and the Congress, as well as the long view

3. Id. at 595-96. But see Freund, Foreword: The.Year of the Steel Case, The Supreme Court, 1951 Term, 66 HaRv. L. Rev. 89, 95 (1952).

4. 343 U.S. at 596.

5. Myers v. United States, 272 U.S. 52 (1926).

6. 343 U.S. at 588.

7. Id. at 597. Mr. Justice Frankfurter also distinguishes the situation presented from a seizure which takes place after a declaration of war by Congress. Id. at 613 . 
of the immediate parties in interest, will not find ready accommodation for differences on matters which, however close to their concern and however intrinsically important, are overshadowed by the awesome issues which confront the world." It is not entirely pleasant to recall that many weeks of costly strike and much more portentous crisis in the posture of military affairs were required before such an accommodation could be found. ${ }^{9}$

\section{The Right to Judicial Review-Legal Interest or Standing}

Mr. Justice Frankfurter has always viewed the problems of case and controversy, or the nature of judicial power, as part of the larger problem of separation of powers. Similarly, he has viewed the question of legal interest to challenge administrative action as part of the larger problem of case and controversy. However, he has also recognized, indeed he has frequently insisted, that a particular question of standing or legal interest to challenge the validity of administrative action must be resolved in the light of the particular statutory provisions authorizing such action and controlling the jurisdiction of the court to review. In the latter respect, his concern for the jurisdiction of the federal courts has been at least as keenly aroused as his concern for the integrity of the administrative process. Appropriately, one of the first opinions which the Justice wrote for the Court in the area of administrative law-Rochester Tel. Corp. v. United States ${ }^{10}$-reflected all of these considerations.

The Rochester case involved a suit under section $402(a)$ of the Communications Act of 1934 to set aside an order of the Federal Communications Commission classifying Rochester "as subject to all common carrier provisions of the Communications Act of 1934, and, therefore, subject to all orders of the Telephone Division."11 This order was, in turn, based on a finding that Rochester was under the control of the New York Telephone Company and therefore not entitled to exemption as a mere connecting carrier under another section of the act. The government rather belatedly challenged the jurisdiction of the district court to entertain the bill on the ground that the Commission's action was not reviewable because it was a "negative order" within the meaning of the "negative order" doctrine developed by decisions under the Urgent Deficiencies Act with particular reference to orders of the Interstate Commerce Commission. This jurisdictional objection could conceivably, as the concurring opinion of Justices Butler and McReynolds suggest, have been dismissed rather bluntly on the theory that the particular order at issue was but the culmination of a series of affirmative orders requiring Rochester to file voluminous reports with the Commission. Such a disposition, however, would have been essentially inconsistent with at least some of the prior decisions applying the negative order doctrine, and would have only postponed the necessity for the fundamental re-

8. Id. at 614.

9. See Hammond, The Steel Strike of 1952, 23 CurRent History 285 (1952).

10. 307 U.S. 125 (1939).

11. Id. at 128 . 
examination and restatement which Mr. Justice Frankfurter undertook in the opinion of the Court. Nevertheless, the ungenerous comment of the concurring opinion that "the Court's discussion, extraneous to the issue involved, confuses rather than clarifies" does contain a modicum of truth. ${ }^{\mathbf{1 2}}$ Perhaps this is partly because Mr. Justice Frankfurter could not quite bring himself, or the Court for which he spoke, to state explicitly which of the prior decisions were in effect being disapproved or overruled.

The principal thrust of the Rochester opinion is to substitute fundamental considerations of case and controversy and equity jurisdiction for the rather formalistic negative order doctrine. As announced by Chief Justice White in Procter \& Gamble Co. v. United States, ${ }^{13}$ that doctrine justified an interpretation of the statutory provisions authorizing review of the Interstate Commerce Commission to "confer jurisdiction only to entertain complaints as to affirmative orders of the Commission."14 For this all-embracing proposition, Mr. Justice Frankfurter substitutes three categories of cases:

"(1) Where the action sought to be reviewed may have the effect of forbidding or compelling conduct on the part of the person seeking to review it, but only if some further action is taken by the Commission. . . .

"(2) Where the action sought to be reviewed declines to relieve the complainant from a statutory command forbidding or compelling conduct on his part. ...

"(3) Where the action sought to be reviewed does not forbid or compel conduct on the part of the person seeking review but is attacked because it does not forbid or compel conduct by a third person. . .."15

With regard to the first category, the Justice has little difficulty demonstrating that judicial review is properly denied in such cases, partly because of "what is implied from the grant of 'judicial power' to determine 'Cases' and 'Controversies,' Art. III, § 2, U.S. Constitution," and partly because of "the procedural philosophy pertaining to the federal courts whereby, ever since the first Judiciary Act, Congress has been loath to authorize review of interim steps in a proceeding." 10 The second category, represented for example by the Lehigh Valley case in which review was denied, ${ }^{17}$ also gives the Justice little difficulty. He finds that the requirements of both case and controversy and equity jurisdiction are satisfied and that "the result in the Lehigh Valley case was reached in the earlier phases of modern administrative law and did not deal with its specific jurisdictional problems in the perspective of underlying principles governing federal equitable jurisdiction."18 Finally, in the third category, of which the Procter \& Gamble case itself is the leading example, the Justice

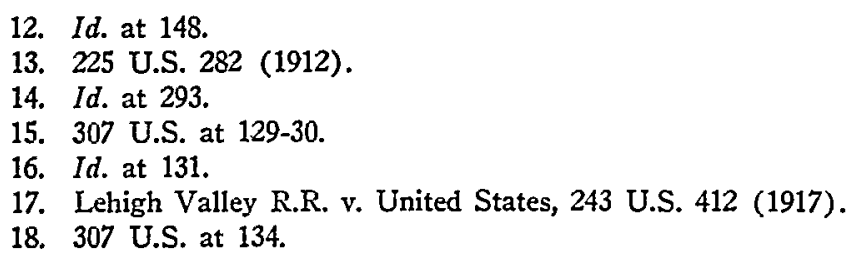


quickly recognizes all the requisite elements of case and controversy, equitable jurisdiction and statutory authorization. Nevertheless, he seems vaguely troubled by the possibility that the result in Procter $\mathcal{E}$ Gamble was dictated in part by general considerations from which "the Court evolved two specific doctrines [primary jurisdiction and administrative finality] limiting judicial review of orders of the Interstate Commerce Commission."19 Quite clearly both the Lehigh Valley and Procter \& Gamble decisions are disapproved, at least in so far as they rest, as they explicitly do, on jurisdictional grounds. But the conclusion as stated is not that unqualified: "We conclude, therefore, that any distinction, as such, between 'negative' and 'affirmative' orders, as a touchstone of jurisdiction to review the Commission's orders, serves no useful purpose, and insofar as earlier decisions have been controlled by this distinction, they can no longer be guiding." 20 Perhaps this is simply the junior Justice's acceptance of the conventional boilerplate by which prior decisions are gently consigned to oblivion; perhaps the equivocation was further motivated by respect for the authors of the Procter \& Gamble and Lehigh opinions, Chief Justice White and Mr. Justice Holmes. ${ }^{21}$ In any event, the result is effectively to disown one of Chief Justice White's contributions to modern administrative lawand this without even mention of the possibility that the negative order doctrine had become enshrined in the statute through long years of congressional acquiescence.

In later years, the Rochester opinion came back to haunt Mr. Justice Frankfurter. The occasion was United States $v$. ICC, decided in 1949.22 There the Court-Justices Frankfurter, Jackson and Burton dissenting-held that the United States, and presumably any other shipper, could bring suit in the federal district court to set aside an order of the Interstate Commerce Commission denying a claim for reparations. ${ }^{23}$ In reaching this result for the Court, Mr. Justice

19. Id. at 139. In further explanation of this possibility, Mr. Justice Frankfurter says: "In the application of relevant canons of judicial review an order of the Commission directing the adoption of a practice might raise considerations absent from a situation where the Commission merely allowed such a practice to continue. But this bears on the disposition of a case and should not control jurisdiction." $I d$. at 142.

20. Id. at 143 .

21. In a footnote to his dissenting opinion in United States v. ICC, 337 U.S. 426,469 n.14 (1949), Mr. Justice Frankfurter says of the examination of cases he had made in the Rochester opinion: "That examination revealed that only one case out of the whole series of cases examined was really determined by the 'negative order' doctrine. That was the only case the Court overruled." It is difficult to quarrel with the author of the opinion, but this conclusion seems to draw an unjustified distinction between the treatment of the Lehigh Valley and the Procter \& Gamble cases. On the face of the opinion itself, either both of the cases were overruled or neither of them was, in so far as the jurisdictional question of reviewability was concerned. Since neither was decided on the merits, the possibility that in one or both the complainant might have lost on the merits anyway is hardly relevant.

22. 337 U.S. 426 (1949).

23. Suit was to be brought under 28 U.S.C. $\$ 41(28)$ (1946) (amended by 28 U.S.C. § 1336 (1952)). 
Black recognized the need to disapprove, at least in part, the Court's holding in Standard Oil Co. v. United States, ${ }^{24}$ which interpreted section nine of the Interstate Commerce Act to deny shippers any judicial review of commission decisions rejecting reparation claims. But according to Mr. Justice Black, "the Standard Oil \$ 9 interpretation barred judicial review of no class of Commission orders except orders already immune from such review under the 'negative order' doctrine. The Standard Oil holding was thus clearly supported by and rooted in the now rejected 'negative order' doctrine."25 In other words, the opinion of the Court in the Rochester case, rather than in United States $v$. $I C C$, overruled Standard Oil. In vain, Mr. Justice Frankfurter called attention to the footnote in Rochester which "explicitly pointed out that 'the main basis' of the Standard Oil decision was not the 'negative order' doctrine but . . . the statutory scheme dealing with reparations." 26 His dissenting opinion, in effect an elaboration of that earlier footnote, convincingly demonstrates that the relevant statutory provisions, as originally written, could reasonably be interpreted to give the shipper seeking reparations a choice between the equally conclusive alternatives of judicial or administrative recourse. ${ }^{27}$

This demonstration can be answered only by the assumption that judicial review of administrative action is properly regarded as the rule rather than the exception. Or, as Mr. Justice Black prefers to put it, "such a sweeping contention for administrative finality is out of harmony with the general legislative pattern of administrative and judicial relationships." 28 Significantly, this state-

24. 283 U.S. 235 (1931).

25. 337 U.S. at 436 .

26. Id. at 467 .

27. The Justice's argument has only one flaw, a flaw created by a decision for which he has often expressed his admiration, Texas and Pac. Ry. v. Abilene Cotton Oil Co., 204 U.S. 426 (1907). As a result of that opinion, in certain situations the shipper does not really have a choice of going first to the courts rather than to the Commission. When he is forced by Abilene to go first to the Commission, the majority says the shipper should have an opportunity to challenge in the courts the validity of the Commission's denial of his claim. Mr. Justice Frankfurter has an answer: The shipper can ask the Commission for a declaration regarding legality of a past practice, but not for damages; thus his damage claim may be saved for court action. Or, he may start his action for damages in the court first and have it stayed instead of dismissed under Abilene, while he goes to the Commission for a determination of the validity of the practice.

Upon one point at least, Mr. Justice Frankfurter's dissent in United States v. ICC is virtually unanswerable. The opinion of the Court concludes that "a Commission order dismissing a shipper's claim for damages under 49 U.S.C. $\$ 9$ is an 'order' subject to challenge under $\$ 28$ U.S.C. (1946 ed.) $\$ 41$ (28)." 337 U.S. at 440-41. It also concludes that the challenge is to proceed before a one rather than three-judge district court. But as Mr. Justice Frankfurter says, "jurisdiction under $\$ 41$ (28) carries also the requirement of a three-judge court. . . . To reject the latter is necessarily to hold that no jurisdiction of the district court is derivable from $\S 41$ (28) of Title 28 , now $\S 1336$." Id. at 461 . In itself, this is a rather small point. However, it suggests that the Court is making up a good part of its law of judicial review out of whole cloth, without much regard for the statutory design.

28. Id. at 433-34. 
ment is annotated by reference to section ten of the Administrative Procedure Act, which provides, inter alia, "any person suffering legal wrong because of any agency action, or adversely affected or aggrieved by such action within the meaning of any relevant statute, shall be entitled to judicial review thereof."20 If this section is indeed a grant of jurisdiction allowing the federal courts to review the validity of administrative action wherever the statutes do not otherwise explicitly provide, much of the legal theory upon which Mr. Justice Frankfurter has based his approach to the right of judicial review may be swept into the discard. For example, in Stark v. Wickard, the Justice dissented from a ruling that milk producers were entitled to bring suit to challenge an order of the Secretary of Agriculture despite the absence of explicit statutory provision:

"Except in those rare instances, as in a claim of citizenship in deportation proceedings, when a judicial trial becomes a constitutional requirement because of "The difference in security of judicial over administrative action,' $N g$ Fung Ho v. White, 259 U.S. 276, 285, whether judicial review is available at all, and, if so, who may invoke it, under what circumstances, in what manner, and to what end, are questions that depend for their answer upon the particular enactment under which judicial review is claimed. Recognition of the claim turns on the provisions dealing with judicial review in a particular statute and on the setting of such provisions in that statute as part of a scheme for accomplishing the purposes expressed by that statute. Apart from the text and texture of a particular law in relation to which judicial review is sought, 'judicial review' is a mischievous abstraction. There is no such thing as a common law of judicial review in the federal courts. The procedural provisions in more than a score of these regulatory measures prove that the manner in which Congress has distributed responsibility for the enforcement of its laws between courts and administrative agencies runs a gamut all the way from authorizing a judicial trial de novo of a claim determined by the administrative agency to denying all judicial review and making administrative action definitive."30

The Court has not yet indicated the extent to which section ten of the Administrative Procedure Act nullifies the validity of this thesis. ${ }^{31}$ In one sense,

29. 60 StAT. 243 (1946), 5 U.S.C. $\$ 1009$ (1952). The provision quoted in the text is introduced by some very significant qualifications: "Except so far as (1) statutes preclude judicial review or (2) agency action is by law committed to agency discretion ...."

30. 321 U.S. $288,312-13$ (1.944).

31. Mr. Justice Frankfurter himself argued for a more liberal interpretation of $\$ 10$ of the Administrative Procedure Act than the Court was willing to adopt in Heikkila v. Barber, 345 U.S. 229 (1953). The Court held that $\$ 10$ did not have the effect of authorizing judicial review of deportation orders by declaratory judgment or injunction proceedings, in addition to habeas corpus proceedings as previously allowed, because the Immigration Act of 1917, as consistently interpreted, "had the effect of precluding judicial intervention in deportation cases except insofar as it was required by the Constitution." Id. at 234-35. The Court apparently feared that the scope of review by way of declaratory judgment would be broader than in habeas corpus proceedings. To this concern, Mr. Justice Frankfurter answered that "a declaratory judgment action under $\$ 10$ (b) can be limited-as it should be-to the scope of review appropriate to the extraordinary remedy of habeas corpus." Id. at 240. But see Rubinstein v. Brownell, 206 F.2d 449 (D.C. Cir. 
the section might provide the springboard for a kind of "common law of judicial review in the federal courts," subject, of course, to the exception recognized in the introductory clause of the section-explicit limitations in particular statutes. ${ }^{32}$ In any event, the problem of determining when a "person is suffering legal wrong" under section ten seems to suggest the type of considerations upon which the Court divided in Stark v. Wickard and Columbia Broadcasting Systcm, Inc. $v$. United States. ${ }^{33}$ And while the Justice's dissents in both of these cases, as well as in United States v. ICC, are shining examples of the lawyer's art at its best, they serve for the most part only to sharpen the significance of what the Court decided.

Fortunately, not all of the Justice's opinions on standing to challenge the validity of administrative action have been devoted to establishing the unsoundness of the Court's interpretation of particular statutes. His concurring opinion in Joint Anti-Fascist Refugee Comm. v. McGrath is a re-examination of the entire problem. ${ }^{34}$ The Justice draws upon cases in which his own views were rejected as well as upon those in which he prevailed, and formulates what might for want of a better term be referred to as a "common law of judicial review." Necessarily, this common law is partly constitutional law. And for the Justice, it naturally commences with the question of case and controversy.

'Limitation on 'the judicial Power of the United States' is expressed by the requirement that a litigant must have 'standing to sue' or, more comprehensively, that a federal court may entertain a controversy only if it is 'justiciable.' Both characterizations mean that a court will not decide a question unless the nature of the action challenged, the kind of injury inflicted, and the relationship between the parties are such that judicial determination is consonant with what was, generally speaking, the business of the Colonial courts and the courts of Westminster when the Constitution was framed. The jurisdiction of the federal courts can be invoked only under circumstances which to the expert feel of lawyers constitute a "case or controversy.' The scope and consequences of the review with which the judiciary is entrusted over executive and legislative action require us to observe these bounds fastidiously."35

However, the law of "standing to sue" is not entirely constitutional law, and the reference to "the business of the Colonial courts and the courts of Westminster when the Constitution was framed" need not be as inhibiting as a first reading would imply. As detailed by the Justice, legal interest to challenge the validity of administrative action may be based on a constitutional right, a statutory right or some comparable common-law right which would have been available had the injury been inflicted by a private person. The injury suffered in Joint Anti-Fascist falls within the last category. If the appellation of "com-

1953), aff'd per curiam by an equally divided Court, 346 U.S. 929 (1954) (reaching a different conclusion under the Immigration Act of 1952).

32. See note 29 supra.

33. 316 U.S. 407 (1942).

34. 341 U.S. 123 (1951).

35. Id. at 150 . 
munist" or "subversive" had been publicly applied by a private individual, instead of by the Attorney General of the United States, and had resulted in substantial damage of the kind alleged, a cause of action would have arisen. To some, including this writer, this analysis by the Justice may seem unduly restrictive. The question might be asked, for example, why substantial injury resulting directly from unauthorized governmental action does not satisfy all the requirements of "legal interest" irrespective of any common-law analogue for the disposition of private controversies. As Mr. Justice Frankfurter quite convincingly demonstrates, however, such an approach would require a reexamination of the postulates of Perkins $v$. Lukens Steel Co., ${ }^{30}$ Tennessee Power Co. v. TV $A^{37}$ and Alabama Power Co. v. Ickes. ${ }^{38}$ If those postulates are accepted, the Justice's opinion in the Joint Anti-Fascist case is the most comprehensive, forthright and satisfactory analysis we have of the problem of legal standing to challenge the validity of administrative action.

\section{Administrative Procedure and the Right to Fair Hearing}

Mr. Justice Frankfurter's opinion in the Joint Anti-Fascist case also contains an elaborate judicial inquiry into the constitutional right to fair hearing in the administrative process. In one respect, this section of the opinion is more satisfactory than the earlier part dealing with legal interest. Although the Justice canvasses virtually all the situations in which the due process right to administrative hearing has been treated by the Supreme Court and all the considerations which have been deemed relevant to the resolution of the question, he carefully eschews any attempt to summarize the results of the inquiry in an all-embracing formula. The Justice explains this forbearance:

'But 'due process,' unlike some legal rules, is not a technical conception with a fixed content unrelated to time, place and circumstances. Expressing as it does in its ultimate analysis respect enforced by law for that feeling of just treatment which has been evolved through centuries of AngloAmerican constitutional history and civilization, 'due process' cannot be imprisoned within the treacherous limits of any formula. Representing a profound attitude of fairness between man and man, and more particularly between the individual and government, 'due process' is compounded of history, reason, the past course of decisions, and stout confidence in the strength of the democratic faith which we profess. Due process is not a mechanical instrument. It is not a yardstick. It is a process. It is a delicate process of adjustment inescapably involving the exercise of judgment by those whom the Constitution entrusted with the unfolding of the process." 30

Consistently with this approach, Mr. Justice Frankfurter does not entirely deny the relevance of the point principally relied upon in the dissenting opinion of Mr. Justice Reed-that ostensibly "there is no deprivation of any property

36. 310 U.S. 113 (1940).

37. Tennessee Elec. Power Co. v. TVA, 306 U.S. 118 (1939).

38. 302 U.S. 464 (1938).

39. 341. U.S. at $162-63$. 
or liberty of any listed organization by the Attorney General's designation." Instead, he counters with the comment: "It would be blindness, however, not to recognize that in the conditions of our time such designation drastically restricts the organizations, if it does not proscribe them." 41 But he expressly recognizes that "the precise nature of the interest that has been adversely affected, the manner in which this was done, the reasons for doing it, ... the protection implicit in the office of the functionary whose conduct is challenged, the balance of hurt complained of and good accomplished-these are some of the considerations that must enter into the judicial judgment."42 Moreover, the Justice does not commit himself with regard to the type of hearing which the Attorney General must accord. For example, he does not state whether the "partial disclosure and hearing in proceedings against a Government employee who is a member of a proscribed organization" 43 afford sufficient protection in that particular context, or would do so if they were adopted by the Attorney General for use in compiling his list of subversive organizations. This cautious refusal to go a step beyond the necessities of the issue presented may try the patience of those anxious for guiding principles to control the course of future proceedings. For those more impressed with the proclivity of ambitious dicta to mislead rather than illuminate, the Justice's rigorous restraint may have much to recommend it. ${ }^{44}$

Another illuminating but more questionable illustration of $\mathrm{Mr}$. Justice Frankfurter's flexible approach to the fair hearing problem is his dissenting opinion in Jay $v$. Boyd. ${ }^{45}$ Involved was the denial of an application for suspension of a deportation order. Under a provision of the Immigration and Nationality Act of 1952, the Attorney General, in his discretion, is authorized to suspend deportation if he considers certain specified conditions satisfied. This authority he had delegated to subordinates under regulations requiring formal hearings to be held but permitting the officers concerned to take into account "confidential information without the disclosure thereof to the applicant, if in the opinion of the officer or the Board making the determination the disclosure of such information would be prejudicial to the public interest, safety, or security."40 In $J a y$, the application had been denied on the basis of such confidential information. Sustaining the denial of suspension, the Court rejected the claim that the procedure followed involved a breach of due process. It relied on the interrelated grounds that due process had been satisfied by a full hearing before the

40. Id. at 202 .

41. Id. at 161 .

42. Id. at 163 .

43. Id. at 173 .

44. Consider, for example, the experience of President Roosevelt relying on Myers v. United States, 272 U.S. 52 (1926), in discharging the Chairman of the Federal Trade Commission, only to be told in Humphrey's Ex'r v. United States, 295 U.S. 602, 626 (1935), that the "expressions . . . which tend to sustain the government's contention . . . are beyond the point involved and, therefore, do not come within the rule of stare decisis."

45. 351 U.S. 345 (1956).

16. Id. at 348 . 
deportation order was issued and that the discretionary suspension powers of the Attorney General were comparable to judicial probation or executive parole powers with regard to which no constitutional right exists to any sort of hearing.

Chief Justice Warren and Justices Black, Douglas and Frankfurter wrote separate dissenting opinions. Each of the first three indicates that he regards use of confidential information in the context of the particular proceeding as a violation of due process. But Mr. Justice Frankfurter makes no mention of due process or other constitutional right. Instead, he argues that Congress has invested the Attorney General, not his subordinates, with the dispensing power, and that "if in his wisdom the Attorney General devises a system for delegating the means for carrying out the responsibility for which Congress has given him discretion, he cannot also delegate his discretion." Then follows this pregnant but puzzling passage:

"If the Attorney General devises, as he has devised, an administrative system for effectuating $\S 244$ (a) (5) of the Act of 1952, administrative arbitrariness is ruled out. If the Attorney General invokes the aid of administrative law, as he has done by establishing a procedure before a special inquiry officer of the Immigration and Naturalization Service and a review of that officer's decision by the Board of Immigration Appeals, these two agencies of administrative law cannot be authorized to defy the presuppositions of a fair hearing. The Attorney General may act on confidential information and Congress has left him to square it with his conscience. But he cannot shelter himself behind the appearance of legal procedurea system of administrative law-and yet infuse it with a denial of what is basic to such a system." 47

The first question suggested by this passage seeks the source of the Attorney General's disability to act in this fashion. Does it arise from the Constitution or the statute or something inherent in the nature of administrative law-a kind of common law of administration? The last seems hardly a serious alternative except in the qualified sense of an emanation from constitutional or general statutory provisions, comparable to the principles of "administrative finality" or "primary jurisdiction." 48 The second possibility, reliance upon the particular statute involved, is hardly more satisfying. As the majority opinion convincingly demonstrates, Congress was concerned with limiting only the Attorney General's affirmative exercise of the suspension power, not his refusal to exercise it. Furthermore, delegation of the Attorney General's authority

47. Id. at 372 .

48. Mr. Justice Frankfurter found implications of a right to full hearing in the statute involved-the War Brides Act-in United States ex rel. Knauff v. Shaughnessy, 338 U.S. 537 (1950). In Shaughnessy v. United States ex rel. Mezei, 345 U.S. 206, 218 (1953), however, another exclusion case, he joined in the dissent of Mr. Justice Jackson which was expressly based on due process grounds. Special circumstances differentiated it from the ordinary exclusion case. Mezei was a permanent resident in this country returning home after a visit abroad, and he was being indefinitely confined on Ellis Island because no other country was willing to receive him. 
apparently was permitted by the statute; the delegation itself was not challenged, and even Mr. Justice Frankfurter does not entirely deny the validity of the delegation apart from the procedure through which it was to be exercised. ${ }^{49}$ Finally, if a constitutional principle embodies "the presuppositions of a fair hearing" to which the Justice refers, that principle must be due process. ${ }^{50}$ However, only an extremely limited conception of due process would operate when the Attorney General delegates his authority, but not when he exercises his own personal judgment. Apparently, the underlying philosophy is that the government cannot employ this semblance of fair hearing without also providing the substance. But what if the Attorney General had provided the same procedures for the actions of his subordinates with the additional opportunity for appeal to himself by the disappointed applicant and, in this appeal, had left himself free to exercise his personal discretion? If this system did not satisfy the standards which the Justice would impose, the Attorney General would be encouraged to eliminate the delegation and the hearing procedure entirely and then to do surreptitiously what he would otherwise do openly-rely heavily on the recommendation of his subordinates. In any event, this possibility seems the major objection to the Justice's rationale; it places a premium upon informal delegation plus the rubber-stamp technique, as opposed to formal delegation with specification of limited procedural protection.

Where the right to a hearing has been conceded and the issue is solely whether the essential elements of fair hearing have been satisfied, Mr. Justice Frankfurter has consistently tolerated administrative procedures which take due account of the needs of administration. And he has been wary of judicial insistence upon administrative imitation of judicial techniques. One of his first opinions touching upon this problem was in the fourth Morgan case. ${ }^{51}$ Writing for the Court, he significantly qualifies Chief Justice Hughes's assertion in the first Morgan case that the "officer who makes the determinations must consider and appraise the evidence which justifies them."52 Speaking of the Secretary of Agriculture's testimony in the court below "regarding the process by which he reached the conclusion of this order, including the manner and extent of his study of the record and his consultation with subordinates," the Justice says:

49. Mr. Justice Frankfurter refers to a Canadian case, Attorney Gen. v. Brent, 2 D.L.R. $2 \mathrm{~d} 503$ (1956), for support of the proposition that "the nature of a delegated power may preclude redelegation." 351 U.S. at 372 . The Canadian opinions quite clearly rest on the theory that the statute precluded the type of delegation there involved, although reference is also made to the maxim, delegatus non potest delegare. However, the Canadian courts do not seem to have been confronted with the general grant of power to delegate contained in our Immigration Act. 66 STAT. 173, 8 U.S.C. \& 1103 (1952). Consequently, theirs was a much simpler problem.

50. This passage of the opinion concludes with a reference to Ohio Bell Tel. Co. v. PUC, 301 U.S. 292, 300 (1937), in which Mr. Justice Cardozo discusses the "fair hearing essential to due process."

51. United States v. Morgan, 313 U.S. 409 (1941).

52. Morgan v. United States, 298 U.S. 468, 482 (1936). 
"But the short of the business is that the Secretary should never have been subjected to this examination. The proceeding before the Secretary 'has a quality resembling that of a judicial proceeding.' ... Such an examination of a judge would be destructive of judicial responsibility. We have explicitly held in this very litigation that it was not the function of the court to probe the mental processes of the Secretary.' ... Just as a judge cannot be subjected to such a scrutiny, ... . so the integrity of the administrative process must be equally respected. ... It will bear repeating that although the administrative process has had a different development and pursues somewhat different ways from those of courts, they are to be deemed collaborative instrumentalities of justice and the appropriate independence of each should be respected by the other."53

Mr. Justice Frankfurter's most elaborate opinion for the Court upon the issue of fair hearing in the administrative process appears in NLRB v. Donnelly Garment Co.54 In that case, the Court rejected various claims that a rehearing held by the Board after the court of appeals had set aside its order and remanded the case for further proceedings violated both the essentials of fair hearing and the mandate of the court of appeals. The first issue presented was whether the Board was under an obligation to hold an entirely new trial, or whether it could properly reconsider the case upon the original record plus such additional evidence as might be admitted at the second hearing in accordance with the specific rulings of the court of appeals. In holding that the second alternative satisfied both the mandate of the court and the requirements of due process, the Justice says, in part:

"In the context of the opinion remanding the Board's original order and of the nature of the administrative process with which it is entrusted, the Board was justified in not deeming itself under duty to grant a 'new trial' in the sense in which a lower court must start anew when an upper court directs such a new trial. ... From the Court's opinion there appears only a very restricted dissatisfaction with the original proceedings before the Board, calling for a correspondingly restricted correction. ... . Due process does not afford a party the right to treat as rehearsal a hearing on the issues for which the hearing was adequate. And the Wagner Act does not require that ground be covered a second time or piecemeal."

In contrast with this rejection of an analogue in judicial proceedings is the reliance upon judicial custom to dispose of a related issue in the same proceeding. Although the court of appeals, on its first review of the Board's order, rejected the company's claim that the examiner was biased, it ruled on the second review that the Board had improperly denied the company's request for a new examiner. Overruling this holding of the court of appeals, Mr. Justice Frankfurter states:

"The Court seemed to be moved by the generous feeling that a party ought not to be put to trial before an examiner who, by reason of his prior rul-

\footnotetext{
53. 313 U.S. at 422 .

54. 330 U.S. 21.9 (1947).

55. Id. at $227-28$.
} 
ings and findings, may not be capable of exercising impartiality. Certainly it is not the rule of judicial administration that, statutory requirements apart, see Judicial Code $\S 21,28$ U.S.C. $\$ 25$, a judge is disqualified from sitting in a retrial because he was reversed on earlier rulings. We find no warrant for imposing upon administrative agencies a stiffer rule, whereby examiners would be disentitled to sit because they ruled strongly against a party in the first hearing. The Board might have gone beyond the legal compulsions and ordered the new evidence to be heard before a new Examiner who could report with a mind wholly free from prior litigious embroilments. ... In any event, we are not the advisers of these agencies. And we have no right to upset their orders unless they fall afoul of legal requirements." 50

This simultaneous rejection and acceptance of judicial analogies is not offered as evidence of inconsistency. Rather, it serves as a graphic example of the inadequacy of general propositions in this area. Even in the Donnelly case, $\mathrm{Mr}$. Justice Frankfurter found difficulty in conforming to his hands-off policy; he obviously would have preferred that the Board lean over backwards to be fair to the company. ${ }^{57}$ Whether such action would have been compatible with effective administration of a controversial statutory policy is another story.

Mr. Justice Frankfurter's tolerance for the departure of administrative procedures from judicial norms has not always won the approval of his brethren on the Court. He has been particularly willing to make allowances for the necessities of effective administration in cases coming to the Court from the Federal Communications Commission, even at the expense of curtailing the rights of interested parties to a full hearing. For example, in the Ashbacker case, ${ }^{58}$ the Justice dissented from the holding that when two applications for broadcasting licenses are "mutually exclusive,". grant of one before holding a hearing on the other is in effect a nullification of the hearing which the statute guarantees to each applicant before he is denied a license. The Court reasoned that the hearing eventually granted the less favored applicant was bound to be a sham, inasmuch as the Commission had indicated its unwillingness to revoke a license on the ground that a competing applicant was better qualified. Mr. Justice Frankfurter answered that:

"[I]t must be accepted that the Commission, before having taken action, carefully tested, according to its established practice, the claims both of Fetzer and of petitioner by the touchstone of public interest. . . In granting Fetzer's application and setting the denial of the petitioner's down for a hearing after fully canvassing the situation, the Commission brought itself within the explicit provisions of the Communications Act and applied

56. Id. at 236-37.

57. The most difficult issue in the Donnelly case was presented by the Board's partial exclusion of evidence regarding the misconduct of the complainant union. A somewhat similar problem had been presented in NLRB v. Indiana \& Mich. Elec. Co., 318 U.S. 9 (1943), but Mr. Justice Frankfurter explains that the evidence excluded in Donnelly did not have the same significance as that which the Court held should be admitted in the $I \& M$ case.

58. Ashbacker Radio Corp. v. FCC, 326 U.S. 327 (1945). 
them with that flexibility of procedure which Congress has put into the Commission's own keeping."

Similarly, the Justice, in FCC v. National Broadcasting Co., ${ }^{60}$ dissented from the conclusion that a broadcasting station of specified frequency and power was entitled as a matter of right to be a party to a proceeding before the Commission involving the grant of the same frequency and power to another station in another part of the country, such grant creating possible interference in some areas with a clear channel previously assigned to the first licensee. Here again, Mr. Justice Frankfurter observed that admission as a party in the formal hearing was not the only means by which the Commission gave consideration to competing claims. Under the commission rules, the first licensee was entitled to appear and offer evidence on the effect of the proposed grant on its interests. But it had not availed itself of that right or otherwise shown that the Commission had erroneously evaluated the significance of the prospective interference. Under such circumstances, Mr. Justice Frankfurter thought:

"To deny to the Commission the right to require a preliminary showing, such as was found wanting here, before admitting a petitioner to the full rights of a party litigant is to fasten upon the Commission's administrative process the technical requirements evolved by courts for the adjudication of controversies over private interests. . . It is to assume that the modes familiar to courts for the protection of substantial interests are the only permissible modes, regardless of the nature of the subject matter and the tribunals charged with administration of the law."01

Against the background of his position in the communications commission cases, Mr. Justice Frankfurter's agreement with the dissent of Chief Justice Stone from the holding in Bridges $v$. Wixon is not surprising. ${ }^{62}$ The Court there ruled that the use of prior contradictory statements of a witness at a deportation hearing as partial basis for a finding of deportability was so highly

59. Id. at 336-37. Mr. Justice Frankfurter did suggest, in addition, that the Commission's order for a hearing on the petitioner's application should be modified so as to assure the applicant a hearing on the comparative merits of its application.

60. 319 U.S. 239 (1943).

61. Id. at 264. Mr. Justice Frankfurter seems to regard his position in the Ashbacker and National Broadcasting cases as natural corollaries to the position taken in his opinion for the Court in FCC v. Pottsville Broadcasting Co., 309 U.S. 134 (1940). The general theme is, of course, the same-allowance of a greater flexibility in the administrative process than is ordinarily associated with judicial procedures. However, in Pottsville, the particular issue-opportunity to reopen the record and admit additional applicants after a reversal by the Court-also involved protecting the Commission's discretionary powers to choose the best qualified applicant, whereas in Ashbacker and National Broadcasting the Commission's power of uitimate decision was not significantly affected. Furthermore, in Ashbacker, the Justice's suggested method of preserving the truly comparative character of the subsequent hearing seems unlikely to be effective. In National Broadcasting, on the other hand, the substantial rights of the potential intervenors could have been adequately protected without allowing their full participation in matters with which they were not concerned.

62. 326 U.S. 135,166 (1945). 
prejudicial as to vitiate the essential fairness of the proceeding. The Justice was apparently unimpressed by the argument that the particular characteristics of deportation proceedings-the importance of the personal rights involved and the similarity to criminal proceedings-required closer adherence to the highest standards of the judicial process than would a hearing in the context of economic regulation. ${ }^{63}$ However, when, in the Administrative Procedure Act, Congress indicated a general anxiety regarding the fairness of federal administrative proceedings and adopted a policy tending toward their greater judicialization, Mr. Justice Frankfurter was as insistent as any of his brethren upon faithful adherence to the intimations of congressional policy which he found implicit, if not explicit, in the enactment. Thus he joined the majority of the Court in the holding in Wong Yang Sung v. McGrath that the requirements of the Administrative Procedure Act with regard to independent hearing examiners and separation of functions applied to deportation proceedings. ${ }^{64}$ And he dissented from the holding in Marcello $v$. Bonds that exemption from such requirements, explicitly provided for shortly after the Wong Yang Sung case, had been impliedly continued in the Immigration and Nationality Act of $1952 .{ }^{65}$ Whether this enthusiasm for implementing the policies of the Administrative Procedure Act to the fullest possible extent represents simply submission to congressional will or reflects some growing personal concern regarding the justice of the administrative process as currently practiced is best left to private speculation.

\section{Administrative Finality and the Scope of Judicial Review}

The outstanding examples of Mr. Justice Frankfurter's acceptance of the congressional policy reflected in the Administrative Procedure Act are found in his opinions for the Court in Universal Camera Corp. v. NLRB ${ }^{\text {e6 }}$ and NLRB v. Pittsburgh S.S. Co. ${ }^{67}$ The principal issue presented was whether the traditional scope of judicial review of administrative findings of fact-represented by the "substantial evidence" rule-had been modified by section ten

63. See ibid. The most troublesome problem in the Bridges case was whether the agency had violated its own rules in such a way as to deprive the petitioner of protection he would otherwise have enjoyed. See also Colyer v. Skeffington, 265 Fed. 17 (D. Mass. 1920), in which Professors Frankfurter and Chafee participated as amici curiae.

64. 339 U.S. 33 (1950).

65. 349 U.S. 302, 315 (1955). Similarly, Mr. Justice Frankfurter dissented from the ruling in United States v. L. A. Tucker Truck Lines, Inc., 344 U.S. 33 (1952), that the objection of failure to appoint an examiner under the act cannot be considered by the courts if not first raised before the administrative agency, id. at 38 , and from the ruling in Ramspeck v. Federal Trial Examiners Conference, 345 U.S. 128 (1953), that the regulations of the Civil Service Commission, permitting agencies to assign examiners to cases upon the basis of the difficulty of the case and the experience of the examiner, did not violate the statutory provisions designed to protect the independence of the examiners, $i d$. at 143 (dissenting opinion of Justice Black in which Justice Frankfurter concurs).

66. 340 U.S. 474 (1951).

67. 340 U.S. 498 (1951). 
of the act, particularly in so far as it directed the reviewing courts to "review the whole record or such portions thereof as may be cited by any party." 68 Complicating that issue was a considerable difference of opinion between the contending parties on the meaning of the substantial evidence rule prior to possible modification by the Administrative Procedure Act and the corresponding provisions of the Labor Management Relations Act. ${ }^{69}$ The companies contended that under the rule as previously prevailing the courts had considered only evidence tending to support the administrative findings, entirely ignoring all contradictory evidence. This, they said, had been the teaching of the Supreme Court itself when it instructed the lower courts, particularly in labor board cases, that they must not weigh the evidence. The government, on the other hand, contended that the substantial evidence rule had always implied taking into account all evidence relevant to the findings under attack, and that the injunction against weighing the evidence simply implied that the court was not to substitute its own judgment for the judgment of the administrative agency as to the relative weight of the evidence unless the administrative judgment was plainly: unreasonable or contrary to the manifest weight of the evidence. Starting from these different premises on the state of the law existing at the time the statutory provisions were enacted, the parties reached differing conclusions as to the statute's intended effect. The companies' position was that the reference to the "entire record" was designed to correct the one-sided view previously in vogue, the government's that such reference was designed to confirm the substantial evidence rule as then understood and practiced.

The pragmatist may question how these opposing contentions could make any difference in result, particularly since both sides seemed to agree on the correct meaning of the substantial evidence rule as currently embodied in the statutes. An equally pragmatic answer might simply point to the facts that the Court of Appeals for the Second Circuit, which adopted the government's view, had sustained the Board's order, ${ }^{70}$ while the Court of Appeals for the Sixth Circuit had adopted the opposing view and set the order aside. ${ }^{71}$ However, the opinions of Mr. Justice Frankfurter, reversing the Second Circuit and affirming the Sixth, do not rest upon such an oversimplified analysis. In Universal Camera, he expressly recognizes that both circuits might be right, because "enactment of these statutes does not require every Court of Appeals to alter its practice. Some-perhaps the majority-have always applied the attitude reflected in this legislation. To explore whether a particular court should or should not alter its practice would only divert attention from the application of the standard now prescribed to a futile inquiry into the nature of the test formerly used by a particular court."72 Nevertheless, without committing the

68. Administrative Procedure Act $\S 10(\mathrm{e}), 60$ Stat. 244 (1946), 5 U.S.C. $\S 1009$ (e) (1952).

69. 61 STAT. 148 (1947), 29 U.S.C. \& 160(f) (1952).

70. NLRB v. Universal Camera Corp., 179 F.2d 749 (2d Cir. 1950).

71. Pittsburgh S.S. Co. v. NLRB, 180 F.2d 731 (6th Cir. 1950).

72. 340 U.S. at 490 . 
Court to a definitive statement of just what the substantial evidence rule once meant, Mr. Justice Frankfurter quite clearly conveys the idea that the Court will now approach administrative findings of fact with a more critical attitude and will expect that change of attitude to be reflected in the decisions of the lower courts as well. Thus he concludes his exploration of the legislative history of the two statutes with this comment:

"It is fair to say that in all this Congress expressed a mood. And it expressed its mood not merely by oratory but by legislation. As legislation that mood must be respected, even though it can only serve as a standard for judgment and not as a body of rigid rules assuring sameness of application. Enforcement of such broad standards implies subtlety of mind and solidity of judgment. But it is not for us to question that Congress may assume such qualities in the federal judiciary."73

"To find the change so elusive that it cannot be precisely defined does not mean it may be ignored. We should fail in our duty to effectuate the will of Congress if we denied recognition to expressed Congressional disapproval of the finality accorded to Labor Board findings by some decisions of this and lower courts, or even of the atmosphere which may have favored those decisions." 74

In affirming the decision of the Court of Appeals for the Sixth Circuit in the Pittsburgh case, the Justice is more explicit. Of the Supreme Court's prior intimation that Pittsburgh involved evidence sufficiently substantial to meet the requirements of the Wagner Act-the statutory provision then governing board action-the Justice states: "That conclusion, it is proper to say, was reached on the assumption that under the Wagner Act substantiality was satisfied if there was evidence in the record in support of the Board's conclusions."75 And in approving the lower court's subsequent opinion, he elucidates: "The Court of Appeals has now held, in accordance with our own view, that the scope of review had been extended 'beyond the requirements of the Wagner Act,' . . .."76

The decision of the Court of Appeals for the Second Circuit in Universal Camera required more delicate handling. For, although that court regarded the scope of review of labor board decisions as "unaltered by recent legislation," it was also "clear from the court's opinion in this case that it in fact did consider the 'record as a whole,' and did not deem itself merely the judicial echo of the Board's conclusion."77 On this point alone, therefore, the court's decision

73. Id. at 487 .

74. Id. at 490 .

75. Id. at 500. The Supreme Court had previously reversed the court of appeals in Pittsburgh for its refusal to enforce the Board's order on the ground of the trial examiner's bias. In remanding for consideration of the effect of the Administrative Procedure Act and the Taft-Hartley Act on the substantial evidence question, the Court had said: "Without doubting the existence here of evidence substantial enough under the Wagner Act... to warrant the Board's findings, we are not certain whether that standard controls this case." NLRB v. Pittsburgh S.S. Co., 337 U.S. 656, 661 (1949).

76. 340 U.S. at 500 .

77. Id. at 491 . 
was entitled to affirmance. On another subtly related point, however, the Justice found error which required reversal. The court of appeals had concluded that in determining the substantiality of the evidence supporting the Board's findings, it should give no weight to the fact that the examiner's conclusions had been contrary to the Board's. The Justice found this conclusion inconsistent with the statutory provision requiring inclusion of the examiner's report in the record and with the statutory purpose to enhance the role of examiners in the administrative process. This conclusion he explained as follows:

"We do not require that the examiner's findings be given more weight than in reason and in the light of judicial experience they deserve. The 'substantial evidence' standard is not modified in any way when the Board and its examiner disagree. We intend only to recognize that evidence supporting a conclusion may be less substantial when an impartial, experienced examiner who has observed the witnesses and lived with the case has drawn conclusions different from the Board's than when he has reached the same conclusion. The findings of the examiner are to be considered along with the consistency and inherent probability of testimony. The significance of his report, of course, depends largely on the importance of credibility in the particular case. To give it this significance does not seem to us materiaily more difficult than to heed the other factors which in sum determine whether evidence is 'substantial." "78

The least that can be said of the Universal Camera and Pittsburgh opinions is that they constitute a remarkable tour de force in coming as close as possible to explaining the inexplicable. They dance on the edge of revealing the secrets of the conference room and of probing the minds of the Justices, without quite doing either. But beyond that, the decisions are remarkably effective in translating a mood of Congress into a mood of the Supreme Court for the guidance of the lower federal courts. If a point of weakness exists, it is the significance attributed to the examiner's report-a part of the opinion which, as experience has indicated, is particularly susceptible to misconstruction. ${ }^{79}$ Certainly the Justice was correct in saying that the examiner's report should not be ignored. But the reviewing court might properly consider the report for the light it sheds upon the issues involved without equating it to the evidence the substantiality of which is being determined. The analysis of the trial examiner, if different from that of the agency, may reveal weaknesses in the latter's opinion which might otherwise go unnoticed. Where the credibility of witnesses is involved, conflicting evaluations by the examiner and the agency would clearly reveal that the demeanor of the witnesses could not be considered as support for the agency findings. To carry the significance of rejection of the examiner's report further is to disregard the Justice's own prior warnings about the integrity and independence of the administrative process. An administrative agency familiar with the capacities and characteristics of its own examiners might justifiably consider these qualifications in determining the weight to attach to the findings of

78. Id. at $496-97$.

79. See Jaffe, Judicial Reziez: Question of Fact, 69 HaRv. L. Rev. 1020, 1035-38 (1956). 
a particular examiner, especially in so elusive an area as the credibility of witnesses. In fact, there are some reliable indications that appellate courts act in a similar manner with respect to the findings of fact of trial judges with whom they are familiar. The general legislative purpose "to increase the importance of the role of examiners in the administrative process" seems a weak reed upon which to rely in substituting the Court's estimate of the value of the examiner's findings for that of his administrative superiors. While one of the purposes of the act was to enhance the role of the trial examiner, there are explicit provisions calculated to achieve this effect. Congress may well have decided to carry out this particular objective just so far as explicitly provided and no farther. Such a view would be consistent with the attitudes toward statutory interpretation expressed by Mr. Justice Frankfurter in other connections. ${ }^{80}$

But the substantial evidence rule, however interpreted, does not cover all the problems of administrative finality and scope of judicial review. There are other aspects even more elusive of capture in abstract formulae. Questions of law must be distinguished from questions of fact, and the area of administrative discretion in the formulation of policy must be distinguished from each. The nature of the problem is aptly illustrated by reference to the standard provision in public utility statutes requiring that rates be "just and reasonable." Of this requirement in the Natural Gas Act, Mr. Justice Frankfurter, dissenting in FPC v. Hope Natural Gas Co., said:

"But obedience of the requirement of Congress that rates be 'just and reasonable' is not an issue of fact of which the Commission's own determination is conclusive. Otherwise, there would be nothing for a court to review except questions of compliance with the procedural provisions of the Natural Gas Act. Congress might have seen fit so to cast its legislation. But it has not done so. It has committed to the administration of the Federal Power Commission the duty of applying standards of fair dealing and of reasonableness relevant to the purposes expressed by the Natural Gas Act. The requirement that rates must be 'just and reasonable' means just and reasonable in relation to appropriate standards. Otherwise Congress would have directed the Commission to fix such rates as in the judgment of the Commission are just and reasonable; it would not have also provided that such determinations by the Commission are subject to court review." 81

While this thesis cannot be seriously challenged, the Justice's position in Hope is difficult to reconcile with his more general attitudes on both administrative law and public utility regulation. Hope delivered the coup de grace to the "fair value" rate base theory of Smyth v. Ames, ${ }^{82}$ which Professor Frankfurter had long ago forcefully criticized. ${ }^{83}$ Yet $M_{r}$. Justice Frankfurter entirely disasso-

80. See, generally, Frankfurter, Some Reflections on the Reading of Statutes (1947), and, particularly, Addison v. Holly Hill Fruit Products, Inc., 322 U.S. 607, 61218 (1944).

81. 320 U.S. 591,626 (1944).

82. 169 U.S. 466 (1898).

83. Frankfurter, The Public and Its Governanent c. 3 (1930). Compare the concurring opinion in Driscoll v. Edison Light \& Power Co., 307 U.S. 104, 122 (1939), in which 
ciated himself from the Hope holding on the ground that "it will little advance the public interest to substitute for the hodge-podge of the rule in Smyth $v$. Ames . . . an encouragement of conscious obscurity or confusion in reaching a result, on the assumption that so long as the result appears harmless its basis is irrelevant." 84 This may be a justifiable characterization of some parts of the Court's opinion, but little justification can be found for its application to the exhaustive and forthright opinion in which the Commission expressed the basis for its conclusions. True, Mr. Justice Frankfurter asks only that "the Commission should set forth with explicitness the criteria by which it is guided in determining that rates are 'just and reasonable," " and that "it should determine the public interest that is in its keeping in the perspective of the considerations set forth" in the dissenting opinion of Mr. Justice Jackson. ${ }^{85}$ The difficulty with this insistence is that the Commission did express its criteria with unusual explicitness, ${ }^{86}$ while the considerations developed by Mr. Justice Jackson were scarcely urged upon it. $^{87}$

The general thesis expounded by Mr. Justice Frankfurter in the Hope casethat in matters of administrative discretion the reviewing court is at least entitled to insist that the administrative agency explicitly state the considerations which have guided the exercise of its discretion-is a favorite theme to which he frequently returns and which he consistently applies irrespective of the agency concerned. Thus, in Phelps Dodge Corp. v. NLRB, ${ }^{88}$ after recognizing the Board's authority to order the reinstatement of strikers who had obtained substantially equivalent employment elsewhere, the Justice's opinion for the Court rules that the findings of the Board did not sufficiently explain why the policies of the act would be effectuated by such reinstatement. The underlying philosophy is set forth in the following passage:

"The administrative process will best be vindicated by clarity in its exercise. Since Congress has defined the authority of the Board and the procedure by which it must be asserted and has charged the federal courts with the duty of reviewing the Board's orders . . . it will avoid needless litigation and make for effective and expeditious enforcement of the Board's order to require the Board to disclose the basis of its order. We do not intend to enter the province that belongs to the Board, nor do we do so.

the Justice says: "The only relevant function of law in dealing with this intersection of government and enterprise is to secure observance of those procedural safeguards in the exercise of legislative powers which are the historic foundations of due process." Ibid. The Justice would doubtless distinguish this statement from his position in the Hopc casc on the ground that Driscoll involved an attack upon a state commission order where judicial review was predicated largely upon constitutional grounds. Compare, too, the concurring opinion in FPC v. Natural Gas Pipeline Co., 315 U.S. 575, 609 (1942).

84. 320 U.S. at 627 .

85. Id. at $627-28$.

86. Cleveland v. Hope Natural Gas Co., 44 P.U.R. (n.s.) 1 (1942).

87. Compare Detroit v. FPC, 230 F.2d 810 (D.C. Cir. 1956) (setting aside Commission orders purporting to be based on Mr. Justice Jackson's approach).

88. 313 U.S. 177 (1941). 
All we ask of the Board is to give clear indication that it has exercised the discretion with which Congress has empowered it. This is to affirm most emphatically the authority of the Board."ss

The same philosophy is expressed in the Justice's opinion for the Court in the first Chenery case, ${ }^{00}$ where the Court set aside an order of the Securities and Exchange Commission denying the principal officers and directors of a public utility holding company the right to participate in the reorganized company. There the Commission did give the reasons for its action-namely, that the officers claimed this right by virtue of ownership of shares in the original company which they had purchased while the reorganization was in progress before the Commission, in violation of general equitable principles applicable to fiduciaries. But the Court found the principles inapplicable and the reasons inadequate. The Commission also argued before the Court that the requirements of "public interest or the interests of investors or consumers"-the standards of the Public Utility Holding Company Act ${ }^{21}$-justified its action. This contention was rejected on the basis that the Commission had "formulated no judgment upon the requirements of the 'public interest or the interest of investors or consumers' in the situation before it." 92 The opinion did suggest that the transactions in question could not be "outlawed or denied their usual business consequences" unless they fell "under the ban of some standards of conduct prescribed by an agency of government authorized to prescribe such standards." How Hower, the possibility was not foreclosed that the Commission might supply "findings . . . and considerations ... which would justify its order as an appropriate safeguard for the interests protected by the Act."94 And the case was sent back to the Commission for further proceedings not inconsistent with the opinion. When the same order was returned to the Court in the second Chenery case, this time buttressed by new findings concerning the interests of investors and the practicalities of reorganizations, Mr. Justice Frankfurter joined with Mr. Justice Jackson in dissenting from affirmance of the Commission's order. ${ }^{95} \mathrm{Mr}$. Justice Jackson's opinion takes the position that the order was plainly outside the Commission's authority so long as no regulation was in effect which prohibited reorganization managers from making such purchases while the reorganization was in progress. Although there is a good deal of sense in Mr. Justice Jackson's implied suggestion that only by announcement of a general rule could the Commission achieve the prophylactic

89. Id. at 197. The Board did set forth its reasons in a supplemental opinion. In the Matter of Phelps Dodge Corp., 35 N.L.R.B. 418 (1941).

90. SEC v. Chenery Corp., 318 U.S. S0 (1943).

91. 49 Stat. 803 (1935), 15 U.S.C. $\$ 79$ (1952).

92. 318 U.S. at 92.

93. Id. at $92-93$.

94. Id. at 94. In Denver \& R.G.W.R.R. v. Union Pac. R.R., 351 U.S. 321,335 (1956), Mr. Justice Frankfurter, dissenting, took a similar position with respect to an order of the ICC which he believed could not be sustained on the basis of the Commission's findings.

95. SEC v. Chenery Corp., 332 U.S. 194, 209 (1947). 
effect which should properly be its main concern, ${ }^{96}$ there is little justification for his assertion that the second Chenery case is obviously inconsistent with the first. It is also a little painful to find Mr. Justice Frankfurter joining in a diatribe against "conscious lawlessness" and "administrative authoritarianism" which would have been more appropriate as the argumentative hyperbole of outraged counsel.97

Questions of administrative discretion sometimes shade imperceptibly into questions of statutory interpretation and so into the ultimate questions of legislative authority. Particularly is this apt to be true when statutes provide for the application of broad general terms to particular factual situations. Mr. Justice Frankfurter has joined in leading opinions of the Court suggesting that,

96. 'See Dodd, The Chenery Corporation Case: A New Landnark in the Law of Administrative Procedure, 56 HARv. L. REv. 1002 (1943) ; Note, SEC v. Chenery Corp.: A Case Study in Administrative Technique, 62 HARv. L. Rev. 478 (1949).

97. 332 U.S. at 216-17.

Mr. Justice Frankfurter and Mr. Justice Jackson have also generally been in agreement in cases involving judicial review of determinations of the ICC. The outstanding examples are ICC v. Mechling, 330 U.S. 567, 583, 584 (1947), in which they dissented from a decision setting aside an order of the Commission, and New York v. United States, 331. U.S. 284, 351,357 (1947), in which they dissented from a decision sustaining an order of the Commission. Mr. Justice Frankfurter compared the case's when he said in New York, "the Court, only the other day, struck down an order of the Commission for want of adequate findings. Interstate Commerce Commission v. Mechling . . . Although in that case there were explicit findings, the Court deemed them inadequate because they were based on 'unsifted averages.'" Id. at 351. Both cases did involve claims of discrimination and the general problem of whether difference in transportation conditions justified differences in treatment. Beyond that, the problems were so dissimilar as to make comparison unilluminating. The Commission's order in the Mechling case permitted the railroads to apply less favorable rates to traffic coming from connecting water carriers than to similar traffic from connecting rail carriers. The Commission in the New York case found unlawful, and directed the elimination of, differentials in rates on similar traffic as between Official, Southern, and Western Trunk-line territories. In the first case, the Commission found that the differentials were justified by difference in transportation conditions; in the second that they were not. In the New York case, unlike Mechling, the findings were buttressed by elaborate cost studies. True, the dissenting Commissioners were not convinced of the soundness of the cost studies. It is also probably true that Justices Frankfurter and Jacl:son were impressed by the thought that the dissenters included some of the ablest of the Commissioners. Mr. Justice Frankfurter refers to the dissenting views of Commissioners Porter and Barnard, Mr. Justice Jackson to those of Commissioner Mahaffie. However, there were equally able Commissioners in the majority, and the validity of the cost studies themselves seems to have become fairly well established. Compare Official-Southern Divisions, 287 I.C.C. 497 (1953), and Official-Southwestern Divisions, 287 I.C.C. 553 (1953). The Justices may have even suspected that the majority of the Commission was yielding more to the demands of political pressure than to the teaching of their administrative expertise. This is certainly the intimation of Mr. Justice Jackson's reference to Commissioner Eastman's dissent in New York Cent. R.R., 235 I.C.C. 255, 333 (1939). Such considerations are not explicitly embodied in the principles of judicial review of administrative discretion. Perhaps it is better that they should not be, for even the ablest of Commissioners might be wrong, and political pressures may reflect the felt needs of society even more surely than elaborate but inconclusive statistical data. 
in this context, the administrative agency may, within limits, have discretionary authority to determine the exact content of the general language..$^{88}$ The Justice reaches a similar conclusion in his opinion for the Court in O'Leary v. BrownPacific-Maxon, Inc.99 There, the relevant question was whether an accidental death was one "arising out of and in the course of employment." Accepting the administrative determination, Mr. Justice Frankfurter explains that "in part at least, the inferences presuppose applicable standards for assessing the simple, external facts. Yet the standards are not so severable from the experience of industry nor of such a nature as to be peculiarly appropriate for independent judicial ascertainment as 'questions of law." "100 This approach is also illustrated by a case involving application of the term "common carrier" to specific motor vehicle operators under the Interstate Commerce Act. In United States v. Contract Steel Carriers, Inc., Mr. Justice Frankfurter dissented from the Court's holding setting aside a Commission order as not supported by evidence in the record and contrary to the statutory definitions of contract and common carriers, saying for himself and Mr. Justice Harlan:

"We cannot believe that if the evidence, as disclosed by the record, which need not be recited, had appeared in a common-law action against the respondent, a court would be justified in taking the case from the jury, and that if the jury had found against the respondent, its verdict would not be allowed to stand. The finding by the Interstate Commerce Commission that the respondent was a 'common carrier,' and therefore subject to the regulatory provisions of the Act, ought not to have less weight than a jury's verdict."101

In apparent conflict with this approach is Mr. Justice Frankfurter's dissent in $S E C$ v. W. J. Howey Co. ${ }^{102}$ Although that case presented a somewhat analogous problem-the meaning of the terms "security" and "investment contract" within the context of the Securities Act-the background varied from that of Contract Steel Carriers. For the judiciary rather than the administrative agency was the authorized finder of the facts. While the Court reversed the decision of the courts below and accepted the position of the Commission that the transactions involved were "investment contracts," Mr. Justice Frankfurter, the sole dissenter, indicated what he regarded as the controlling considerations :

" 'Investment contract' is not a term of art; it is a conception dependent upon the circumstances of a particular situation. If this case came before

98. E.g., Gray v. Powell, 314 U.S. 402 (1941) ; NLRB v. Hearst Publications, Inc., 322 U.S. 111 (1944). For other examples, see the concurring opinion of Mr. Justice Rutledge, in which Mr. Justice Frankfurter joined, in Board of Governors v. Agnew, 329 U.S. 441, 449 (1947), and Mr. Justice Frankfurter's dissenting opinion in NLRB v. Highland Park Mfg. Co., 341 U.S. 322, 326 (1951).

99. 340 U.S. 504 (1951).

100. Id. at $507-08$.

101. 350 U.S. 409,412 (1956). The decision in the Contract Steel Carriers case was suon overruled by statute. Pub. L. No. 163, 85th Cong., 1st Sess. (Aug. 22; 1957).

102. 328 U.S. 293,301 (1946). 
us on a finding authorized by Congress that the facts disclosed an investment contract' within the general scope of $\$ 2(1)$ of the Securities Act ... the Securities and Exchange Commission's finding would govern, unless. on the record, it was wholly unsupported. But that is not the case before us. Here the ascertainment of the existence of an 'investment contract' had to be made independently by the District Court and it found against its existence. ... The Circuit Court of Appeals for the Fifth Circuit sustained the finding.... If respect is to be paid to the wise rule of judicial administration under which this Court does not upset concurrent findings of two lower courts in the ascertainment of facts and the relevant inferences to be drawn from them, this case clearly calls for its application."103

This passage illustrates the dual concern which often troubles Mr. Justice Frankfurter in resolving problems of administrative law : on the one hand, he stresses that courts should respect the integrity of the administrative process; on the other, he emphasizes with equal force that the Supreme Court must also respect the integrity of the lower federal courts.

\section{Conclusion}

Discussion of a Justice's work on the Court solely in terms of his opinions has often been recognized as at best an inadequate, and sometimes misleading, measure of his contribution. Perhaps this thesis is less applicable to Mr. Justice Frankfurter than to a good many other Justices. He has not discernibly hesitated to write specially concurring opinions, as well as dissenting opinions, in order to express some nuance which was not reflected in the opinions of his brethren. Nevertheless, a good deal must have been expressed in the conference room or on the margins of draft opinions which has not been revealed in the published opinions. Within these limitations, the general pattern of Mr. Justice Frankfurter's contribution to the work of the Court in the field of administrative law is faithfully recorded in his opinions.

With the notable exception of the Universal Camera and Pittsburgh decisions, most of the Justice's outstanding majority opinions in this area were written relatively early in his judicial career. This circumstance is not at all surprising, for during that period our administrative law was in considerable ferment, and Mr. Justice Frankfurter was assigned the job of re-examining some of the ancient postulates and formulating new principles to meet a variety of new problems. The period included the Rochester, Pottsville and fourth Morgan opinions, all of which will remain outstanding landmarks so long as the problems of administrative law demand attention. ${ }^{104}$ More recently, ad-

103. Id. at 301-02.

104. The immediate effect of the decision in FCC v. Pottsville Broadcasting Co., 309 U.S. 134 (1940), was considerably modified by amendment of the Communications Act, requiring the Commission, in the event of the reversal of an order of the Commission by judgment of a court, "to forthwith give effect thereto, and unless otherwise ordered by the court, to do so upon the basis of the proceedings already had and the record upon which said appeal was heard and determined." 66 STAT. 720,47 U.S.C. $\$ 402(\mathrm{~h})$ (1952). 
ministrative law has been involved in a somewhat different kind of ferment, with some of the erstwhile defenders of the administrative process distressed by its propensities for giving short shrift to the rights of individuals in the civil liberties field, ${ }^{105}$ while others concern themselves over its inability to provide vigorous and independent statesmanship in matters of economic regulation. ${ }^{100}$ For the most part, Mr. Justice Frankfurter has not exhibited any such disenchantment with the administrative process, perhaps because he did not expect as much of it as did some of his younger disciples, perhaps because he has always been equally, if not more, concerned with the problem of determining the appropriate role of the judiciary in relation to the other institutions of government. Thus, he has been more ready than many of his brethren to accept the dangers of administrative finality simply because Congress has chosen to accept them. Yet he has also been prepared to give hospitable welcome to an apparent change of congressional policy which would liberalize both the opportunity and scope of judicial review. With regard to safeguarding the right to hearing, he has been as insistent as any of his colleagues on the Court in terms of the ultimate result, although he has tried as much as possible to avoid sweeping constitutional generalizations and to rely instead upon statutory implications or even administrative commitments as the basis of the right. Finally, when examining the exercise of administrative discretion, he has obviously tried to avoid partiality between different policies, so long as they were within the statutory framework; the most that he has asked of any agency has been a rational explanation for its choice among competing policies authorized by statute. This demand has been applied consistently to the various agencies, as much to the ICC as to the SEC, as much to the Labor Board as to the Power Commission. All that the Justice can be accused of by way of partiality among the various agencies is that he may have written more knowledgeably and sympathetically of the problems of the ICC than of those of the SEC, and perhaps similarly of the problems of the Labor Board and the Communications Commission as compared with those of the Power Commission. However, even the most objective and impartial of parents may have difficulty in wholly concealing different degrees of reluctance when faced with the necessity of chastising wayward offspring.

105. See GeLlhorn, Individual FreEdom and GoverNMENTAL Restraints c. I (1956).

106. Compare Schwartz, Legal Restriction of Competition in the Regulated Industries: An Abdication of Judicial Responsibility, 67 Harv. L. Rev. 436 (1954); Jaffe, The IEffective Limits of The Administrative Process: A Reevaluation, 67 HaRv. L. REv. 1105 (1954). 